\title{
Comparison of 25-hydroxyvitamin D levels in exclusively and non-exclusively breastfed infants
}

\author{
Analysa Margaretha Bogar, Helena Anneke Tangkilisan, Hesti Lestari
}

\begin{abstract}
Background Vitamin D is an essential nutrient for the prevention of rickets. Human milk typically contains a vitamin D concentration of $25 \mathrm{IU} / \mathrm{L}$ or less. Breastfed infants are at risk of vitamin D deficiency. Previous studies conducted in countries with four seasons have reported that risk factors associated with vitamin $\mathrm{D}$ deficiency influence the vitamin $\mathrm{D}$ status in exclusively breastfed infants.

Objective To compare the levels of 25-hydroxyvitamin D $(25(\mathrm{OH}) \mathrm{D})$ in exclusively and non-exclusively breastfed infants.

Methods This cross-sectional study was conducted in Singkil District, Manado from February to May 2011. Of 48 Posyandu (Integrated Health Center), 4 were chosen to be the sources of subjects for this study. Subjects were collected consecutively among infants aged 6-7 months. The resulting exclusively and non-exclusively breastfed groups had 36 infants each.

Results The mean 25(OH)D level in the exclusively breastfed group was $61.75 \mathrm{nmol} / \mathrm{L}$ (95\% CI 58.02 to 65.48$)$ and in the nonexclusively breastfed group was $85.09 \mathrm{nmol} / \mathrm{L}$ (95\% CI 79.49 to 90.68). The difference in $25(\mathrm{OH}) \mathrm{D}$ levels in the two groups was statistically significant. However, $25(\mathrm{OH}) \mathrm{D}$ levels of both groups were within the normal range.

Conclusion The 25(OH)D level was significantly lower in exclusively breastfed infants compared to that in non-exclusively breastfed infants, but both levels were still in the normal range. [Paediatr Indones. 2012;52:157-60].
\end{abstract}

Keywords: vitamin $D$; deficiency; exclusive breastfeeding

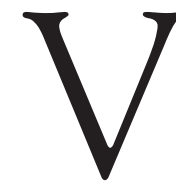

itamin D is an essential nutrient for the prevention of rickets and is required for optimal absorption of dietary calcium and phosphate. ${ }^{1-2}$ There has been a resurgence of vitamin $\mathrm{D}$ deficiency and rickets among infants and children, with reports emerging from the United States, England, Canada, India, and Pakistan. ${ }^{3-7}$ Breastfed infants appear to be at higher risk for vitamin D deficiency. Vitamin D deficiency may occur in exclusively breastfed infants with insufficient exposure to sunlight, high levels of skin pigmentation, and inadequate vitamin $\mathrm{D}$ supplementation. ${ }^{8}$

Although it is clear that human milk is the best nutritive substance for infants during the first year of life, there has been concern about the adequacy of human milk in providing vitamin D. Human milk typically contains a vitamin D concentration of 25 IU/L or less. ${ }^{9}$ The vitamin D content of human milk is quite variable and is affected by sunlight exposure, maternal vitamin $\mathrm{D}$ intake, the form of vitamin $\mathrm{D}$ taken (D2 or D3), race, and amount of clothing that covers the body surface. Maternal vitamin D

From the Department of Child Health, Sam Ratulangi University Medical School, Manado, Indonesia.

Reprint requests to: Analysa M. Bogar MD, Department of Child Health, Sam Ratulangi University Medical School, Prof. Dr. R. D. Kandou Hospital, Jl. Raya Tanawangko, Manado, Indonesia. Tel. +62-431-821652. Fax.+62-431-859091. E-mail: analysa_b@yahoo.com 
status is important and related to vitamin D status in exclusively breastfed infants. ${ }^{6,10}$

Previous studies have found high prevalence of vitamin $\mathrm{D}$ deficiency in exclusively breastfed infants to be associated with risk factors. However, those studies were conducted in countries with four seasons, hence, there were limitations to subjects' sun exposure time. There have been few studies on vitamin D deficiency in Indonesian infants, particularly in Manado. In this study, we aimed to compare $25(\mathrm{OH}) \mathrm{D}$ levels in exclusively and non-exclusively breastfed infants.

\section{Methods}

This cross-sectional study was held in the Singkil District, Manado, from February to May 2011. We used simple random sampling to choose 4 out of 48 Posyandu (Integrated Health Center) in the area as sources for our subjects. Subjects were collected consecutively from infants aged 6-7 months from the 4 chosen Posyandu (Integrated Health Center), resulting in 36 exclusively breastfed infants and 36 non-exclusively breastfed infants who met the inclusion criteria. Exclusive breastfeeding was defined as consumption of human milk with no supplementation of any type (no water, juice, non-human milk, or food). Non-exclusive breastfeeding was defined as consumption of human milk, as well as formula milk, fruit juice or food. The type of breastfeeding was determined by questionnaire filled by subjects' parents.

The inclusion criteria were healthy, exclusively and non-exclusively breastfed infants (aged 6-7 months) without malnutrition. We excluded low birth weight infants, infants who were routinely given 400 IU vitamin $D$ supplementation daily for more than 2 months and those who used medications known to affect vitamin $\mathrm{D}$ metabolism during the previous 3 months. Informed consent was obtained from all subjects' parents.

One blood specimen $(6 \mathrm{ml})$ was obtained from each subject. Serum 25(OH)D levels were measured by enzyme immunoassay technique, with IDS OCTEIA 25-hydroxy vitamin D kit, (IDS, 10 Didcot Way, Boldon, UK).

Results were analyzed by t-test and simple correlation analysis using SPSS version 19 software. A $\mathrm{P}$ value of $<0.05$ was considered to be statistically significant.

\section{Results}

The characteristics of the subjects are shown in Table 1 . There were no differences in gender, body weight, or body length between the 2 groups.

There was a significant difference in the mean $25(\mathrm{OH}) \mathrm{D}$ level between the 2 groups, 62 (SD 11.0) $\mathrm{nmol} / \mathrm{L}$ in the exclusively breastfed group and 85 (SD $16.5) \mathrm{nmol} / \mathrm{L}$ in the non-exclusively breastfed group $(\mathrm{P}<0.001)$, as shown in Table 2.

\section{Discussion}

Vitamin D may be obtained from the diet and from skin exposure to sunlight. Exposure of the skin to the sun's UV rays induces the photolytic conversion of

Table 1. Characteristics of subjects

\begin{tabular}{lcc}
\hline Characteristic & $\begin{array}{c}\text { Exclusively breastfed } \\
\mathrm{n}=36\end{array}$ & $\begin{array}{c}\text { Non-exclusively breastfed } \\
\mathrm{n}=36\end{array}$ \\
\hline Male gender, $\mathrm{n}$ & 18 & 18 \\
Mean body weight, $\mathrm{kg}(\mathrm{SD})$ & $6.8(0.60)$ & $6.7(0.48)$ \\
Mean body length, $\mathrm{cm}(\mathrm{SD})$ & $63.7(1.85)$ & $64.08(2.24)$ \\
\hline
\end{tabular}

Table 2. Serum 25(OH)D levels levels in the exclusively and non-exclusively breastfed infants

\begin{tabular}{lccccc}
\hline \multirow{2}{*}{ Group } & \multicolumn{4}{c}{ 25(OH)D level $(\mathrm{nmol} / \mathrm{L})$} & \multirow{2}{*}{ t-test } \\
\cline { 2 - 5 } & Mean & SD & Median & $95 \% \mathrm{Cl}$ & \\
\hline Exclusively breastfed & 61.75 & 11.02 & 65.30 & 58.02 to 65.48 & $\mathrm{P}<0.001$ \\
Non-exclusively breastfed & 85.09 & 16.54 & 79.55 & 79.49 to 90.68 & \\
\hline
\end{tabular}


7-dehydrocholesterol to previtamin D3 followed by thermal isomerization to vitamin D3. Serum $25(\mathrm{OH})$ $\mathrm{D}$ is considered to be the most reliable and appropriate biochemical marker of vitamin $\mathrm{D}$ status with a halflife of approximately 3 weeks. It is generally accepted that of the circulating vitamin $\mathrm{D}$ metabolites, serum $25(\mathrm{OH}) \mathrm{D}$ measurements best reflect clinical vitamin D status. ${ }^{1,2}$

We observed a significantly lower $25(\mathrm{OH}) \mathrm{D}$ level in the exclusively breastfed group compared to the non-exclusively breastfed group, although neither group was considered to be vitamin D deficient. Similarly, other studies reported lower 25(OH)D levels in exclusively breastfed infants than in non-exclusively breastfed infants. $8,11-13$

We found that the mean $25(\mathrm{OH}) \mathrm{D}$ level was in the normal range for the exclusively breastfed group. However, previous studies reported vitamin D deficiency in exclusively breastfed infants. A possible reason for this difference is that some studies were conducted in four-season countries, while our study was conducted in the sunny, tropical country of Indonesia. Sunlight exposure plays an important role in endogenous cutaneous vitamin D synthesis. ${ }^{14}$ Other reasons for the lack of deficiency may be explained by our inclusion criteria. Our subjects were wellnourished infants, implying adequate vitamin $\mathrm{D}$ intake by their mothers. In addition, our subjects typically wore clothing that did not cover all body surfaces.

Studies from India and Pakistan, countries with many hours of sunlight, also reported vitamin $\mathrm{D}$ deficiency in exclusively breastfed infants and their lactating mothers. A reason for this difference might be due to risk factors that cause vitamin D deficiency, including low socio-economic levels associated with insufficient mothers' and infants' dietary vitamin $\mathrm{D}$ intake, indoor confinement during the day, darker skin pigmentation, and mothers' clothing covering much or all of the body when outside. $6,7,15$ Their findings were consistent with a Saudi Arabian study that also found a high prevalence of vitamin D deficiency in exclusively breastfed infants. Low maternal vitamin D status was thought to be due to the cultural use of clothing to cover all body surfaces. ${ }^{16,17}$

The difference in $25(\mathrm{OH}) \mathrm{D}$ levels between exclusively and non-exclusively breastfed infants may also be because vitamin $\mathrm{D}$ content in human milk is low, affecting the exclusively breastfed infant's vitamin D status. Human milk typically contains a vitamin $\mathrm{D}$ concentration of $25 \mathrm{IU} / \mathrm{L}$ or less. Thus, the recommended intake dosage of vitamin $\mathrm{D}$ cannot be met with human milk as the sole source of vitamin $\mathrm{D}$ for the exclusively breastfeeding infant, especially in preterm infants and infants with limited sun exposure. ${ }^{18,19}$ In contrast, the non-exclusively breastfed infant receives vitamin D-fortified infant food and formula. Vitamin D insufficiency or deficiency in infants who are exclusively breastfed can be prevented by increasing sunlight exposure and/or increasing maternal vitamin D intake. ${ }^{18,20}$

It has been estimated that $20 \%$ of maternal vitamin $\mathrm{D}$ is transferred through milk to the exclusively breastfed infant. Exclusively breastfed infant vitamin D status is correlated with maternal vitamin D status. Low maternal vitamin D status, inadequate sunlight exposure and inadequate vitamin $\mathrm{D}$ supplementation are risk factors for vitamin D deficiency in exclusively breastfed infants. ${ }^{14}$

Circulating 25(OH)D levels in breastfed infants have been shown to be directly related to the vitamin D content of mother's milk. Available evidence indicates that if the vitamin $\mathrm{D}$ status of the lactating mother is adequate, her nursing infant will maintain a "minimally normal" nutritional vitamin D status. With breast milk vitamin $\mathrm{D}$ content depending on the vitamin $\mathrm{D}$ status of the lactating mother, it is very important to maintain maternal vitamin $\mathrm{D}$ status by increasing sunlight exposure, taking adequate vitamin $\mathrm{D}$ in the diet and/or taking vitamin $\mathrm{D}$ supplementation. ${ }^{10}$

A limitation of this study is that we did not adjust for all potential risk factors, such as maternal vitamin D status, sunlight exposure, socio-economic factors and maternal diet, all of which may influence results. Sunlight exposure and skin pigmentation in this study were considered to be uniform, since all subjects lived in one area and were of the same race. Another limitation was that exclusively breastfed infants were categorized based on parents' information on the questionnaire. Infants in the age range of 6-7 months may have been given food or formula containing vitamin $\mathrm{D}$ fortification, thereby influencing the results.

In conclusion, we found significantly lower $25(\mathrm{OH}) \mathrm{D}$ levels in exclusively breastfed infants than in non-exclusively breastfed infants. 


\section{References}

1. Norman AW, Bouillon R. Vitamin D nutritional policy needs a vision for the future. Exp Biol Med. 2010;235:1034-45.

2. Dusso AS, Brown AJ, Slatopolsky E. Vitamin D. Am J Physiol Renal Physiol. 2005;289:8-28.

3. Ziegler EE, Hollis BW, Nelson SE, Jeter JM. Vitamin D deficiency in breastfed infants in Iowa. Pediatrics. 2006;118:603-10.

4. Callaghan AL, Moy RJ, Booth IW, Debelle G, Shaw NJ. Incidence of symptomatic vitamin $\mathrm{D}$ deficiency. Arch Dis Child. 2006;91:606-7.

5. Ward LM, Gaboury I, Ladhani M, Zlotkin S. Vitamin D-deficiency rickets among children in Canada. CMAJ. 2007;177:161-6.

6. Balasubramanian S, Ganesh R. Vitamin D deficiency in exclusively breast-fed infants. Indian J Med Res. 2008;127:250-5.

7. Atiq M, Suria A. Maternal vitamin-D deficiency in Pakistan. Acta Obstet Gynecol Scand. 1998;77:970-3.

8. Greer FR. 25-Hydroxyvitamin D: functional outcomes in infants and young children. Am J Clin Nutr. 2008;88:529-33.

9. Lammi-Keefe CJ. Vitamin D and E in human milk. In: Jensen RG, ed. Handbook of milk composition. New York, NY: Academic Press; 1995. p.706-10.

10. Hollis BW, Wagner CL. Assessment of dietary vitamin D requirements during pregnancy and lactation. Am J Clin Nutr. 2004;79:717-26.

11. Gordon CM, Feldman HA, Sinclair L, DePeter KC, Grace E. Prevalence of vitamin $D$ deficiency among healthy infants and toddlers. Arch pediatr adolesc Med. 2008;162:980-3.

12. Weisberg P, Scanlon KS, Li R, Cogswell ME. Nutritional rickets among children in United States: review of cases reported between 1986 and 2003. Am J Clin Nutr. 2004;80:1697-1705.
13. Cabezuelo HG, Vidal MS, Abeledo GA, Frontera I. 25-Hydroxyvitamin D levels in infants. Relation with breastfeeding. An Pediatr. 2007;66:491-5.

14. Misra M, Pacaud D, Petryk A, Collett-Solberg PF, Kappy M. Vitamin D deficiency in children and its management: Review of current knowledge and recommendations. Pediatrics. 2008;122:398-17.

15. Seth A, Marwaha RK, Singla B, Aneja S, Mehrotra P, Sastry A, et al. Vitamin D nutritional status of exclusively breast fed infants and their mothers. J Pediatr Endocrinol Metab. 2009;22:241-6

16. Dawodu A, Agarwal M, Hossain M, Kochiyil J, Zayed R. Hypovitaminosis D and vitamin D deficiency in exclusively breastfeeding infants and their mothers in summer: A justification for vitamin $D$ supplementation of breastfeeding infants. Pediatrics. 2003;142:169-73.

17. Saadi HF, Dawodu A, Afandi B, Zayed R, Benedict S, Nagelkerke N, et al. Effect of combined maternal and infant vitamin $\mathrm{D}$ supplementation on vitamin D status of exclusively breastfed infants. Matern Child Nutr. 2009;5:25-32.

18. Gartner LM, Morton J, Lawrence RA, Naylor AJ, O'Hare D, Schanler RJ, et al. American Academy of Pediatrics Section on Breastfeeding. Breastfeeding and the use of human milk. Pediatrics. 2005;115:496-06.

19. Hendarto A, Pringgadini K. Nilai nutrisi air susu ibu. In : Hegar B, Suradi R, Hendato A, Partiwi IGA, ed. Bedah Asi. Jakarta: Ikatan Dokter Anak Indonesia cabang DKI Jakarta; 2008. p.45-55.

20. Wagner CL, Greer FR; Section on Breastfeeding and Committee on Nutrition, American Academy of Pediatrics. Prevention of rickets and vitamin $\mathrm{D}$ deficiency in infants, children and adolescents. Pediatrics. 2008;122:1142-52. 